\title{
TINGKAT KEPUASAN MAHASISWA TERHADAP PENGGUNAAN MEDIA E-LEARNING DI ERA PANDEMI COVID 19
}

\section{STUDENT SATISFACTION LEVEL OF USAGE E-LEARNING MEDIA IN THE ERA OF THE COVID PANDEMIC 19}

\author{
Ahmad Al Munawar*1, Fuadaturrahmah ${ }^{2}$ \\ ${ }^{1}$ Sekolah Tinggi Olahraga dan Kesehatan Bina Guna \\ ${ }^{2}$ Akademi Maritim Belawan \\ *Corresponding author: a.almunawar16@gmail.com
}

\begin{abstract}
ABSTRAK
Penelitian ini dilakukan pada Perguruan Tinggi di Sumatera Utara. Penelitian ini bertujuan untuk mengetahui kepauasan mahasiswa dalam penggunaan media e-learning di era pandemi covid 19. Jenis penelitian ini merupakan deskriptif kualitatif dengan metode survey. Populasi dalam penelitian ini adalah seluruh Perguruan Tinggi di Sumatera Utara. Sampel yang digunakan berjumlah 220 orang dengan kriteria telah duduk pada semester 4 dan berstatus mahasiswa aktif. Penarikan sampel dengan teknik random sampling. Teknik pengambilan data menggunakan metode kuesioner tertutup yang terdiri dari 20 pertanyaan. Analisis data dengan analisis deksriptif kualitatif yang disajikan dalam kategori berupa persentase. Hasil analisis data menunjukkan bahwa tingkat kepuasan mahasiswa sudah cukup baik jika ditinjau dari kemampuan dosen dalam menyajikan perkuliahan, pemilihan dan penggunaan media elearning yang baik dan mudah diakses namun pada tingkat efesiensi pembelajaran masih tergolong cukup.
\end{abstract}

Kata Kunci : Tingkat kepuasan; Media e-learning; Covid 19.

\begin{abstract}
ABSTRACK
This research was concuted on College at Sumatera Utara. This study aims to determine students satisfaction in using e-learnig media in the era of the covid 19 pandemic. This type of research is decriptive qualitative by the survey method. Population in this study is all college at Sumatera Utara. The sample used was 220 people with the creteria for having sat in semester 4 and have the status as an active student. Sampling with random sampling technique. The data collection technique used a closed questionare method consisting of 20 questions. Data analysis with qualitative descriptive analysis presented in the catagory of presentation. The results of data analysis show that the level of students statisfication is quite good if viewed from the ability of the lecture in presenting lectures selection and use of good e-learning media and easily accesible but at the level of learning efficiency it is still quite sufficient.
\end{abstract}

Keyword : Satisfaction Level; E-Learning Media; Covid 19. 


\section{PENDAHULUAN}

Covid 19 merupakan suatu jenis virus baru yang di temukan pada awal tahun 2000 di Wuhan, Tiongkok. Virus ini menyerang organ pernafasan manusia sehingga manusia tersebut mengalami kesulitan bernafas. Disinyalir penyebaran virus ini melalui interaksi manusia dengan manusia atau trafick human (Relman, 2020). Penyebaran virus yang disebut dengan Serve Acute Respiratory Syndrome Coronavirus-2 (SARS-CoV-2) ini cukup cepat dan meluas di segala penjuru dunia, setidaknya terdapat 65 negara terjangkit virus ini termasuk Indonesia menurut data World Health Organization pada Maret 2020 (PDPI, 2020).

Pada kasus penyebaran virus Covid-19 di Indonesia sendiri terjadi lonjakan yang cukup besar. Dari data yang diperoleh pada Senin (16/3) kasus terdampak masih 134 orang dengan jumlah kematian lima jiwa, informasi per Kamis (19/3) yang terdampak meroket menjadi 227 dengan kematian 19 jiwa. Tentu menjadi kekhawatiran karena kasus ini terus membesar resikonya dan mengancam di banyak sektor termasuk pada sektor pendidikan.

Tindakan pencegahan penyebaran virus corona di sektor pendidikan harus segera dilaksanakan dengan cepat dan sigap, salah satunya dengan kebijakan "memindahkan" kegiatan belajar mengajar yang seyogyanya dilaksanakan disatuan pendidikan menjadi kegiatan pembelajaran jarak jauh dimana peserta didikanya berada dirumah masing-masing atau yang dikenal dengan istilah Pembelajaran Daring.

Pemanfaatan teknologi informasi dan komunikasi diberdayakan sebagai sarana pembelajaran jarak jauh. Kegiatan pembelajaran dalam jaringan (daring) diprioritaskan untuk mengembangkan sistem pembelajaran jarak jauh (distance learning) untuk mendukung perluasan kesempatan dan pendalaman pemahaman mahasiswa terhadap topik yang disajikan. Teknologi infomasi dan komunikasi akan dimanfaatkan secara optimal dalam fungsinya sebagai media pembelajaran, dan juga untuk memfasilitasi proses pembelajaran. Selain itu, pembelajaran daring ditujukan untuk memberikan akses yang tidak terbatas ruang dan waktu tatap muka yang merupakan salah satu kendala bagi mahasiswa untuk dapat melatih keterampilan mereka.

Penggunaan media E-learning yang merupakan support dari pembelajaran itu sendiri telah "akrab" dengan aktivitas belajar mahasiswa. Berbagai bentuk media aplikasi seperti Google Classroom, Schoology, Edmodo, Zoom, Webex, atau berbagai jenis aplikasi yang berbasis android lainnya pun sudah menjadi opsi mutlak dalam peroses pembelajaran di dunia pendidikan. Penelitian ini bertujuan mencari jawaban atas kepuasan dalam penggunaan media e-learning berbasis android pada dunia pendidikan, mengapa media tersebut menjadi menarik dan layak digunakan serta keunggulan apa sajakah yang dimiliki media tersebut.

Media e-learning tersusun dari kata electronica dan learning. E-learning berarti pembelajaran dengan menggunakan jasa bantuan perangkat elektronika. Jadi dalam pelaksanaannya, elearning menggunakan jasa audio, video atau perangkat komputer atau kombinasi dari ketiganya. Dengan kata lain e-learning adalah pembelajaran yang dalam pelaksanaannya didukung oleh jasa teknologi seperti telepon, audio, videotape, transmisi satelite atau komputer.(Tafiardi, 2005) Sejalan dengan itu, Onno W. Purbo (dalam Amin, 2004) menjelaskan bahwa istilah "e" dalam e-learning adalah segala teknologi yang digunakan untuk mendukung usahausaha pengajaran lewat teknologi elektronik internet. Internet, satelit, tape audio/video, tv interaktif, dan CD-ROM adalah sebagian dari media elektronik yang digunakan. Pengajaran boleh disampaikan pada waktu yang sama (synchronously) ataupun pada waktu yang berbeda (asynchronously).

Menurut Rusman dkk (2011: 264) e-learning memiliki karakteristik, antara lain (a) interactivity (interaktivitas); (b) independency (kemandirian); (c) accessibility (aksesibilitas); (d) enrichment (pengayaan). E-learning dapat didefinisikan sebagai sebuah bentuk teknologi informasi yang diterapkan di bidang pendidikan dalam bentuk dunia maya. Istilah e-learning lebih tepat ditujukan sebagai usaha untuk membuat sebuah transformasi proses pembelajaran yang ada di sekolah atau perguruan tinggi ke dalam bentuk digital yang dijembatani teknologi internet (Munir, 2009: 169). Seok (2008:725) menyatakan bahwa "e-learning is a new form of pedagogy for learning in the 21st century. e-Teacher are elearning 
instructional designer, facilitator of interaction, and subject matter experts". Penerapan e-learning untuk pembelajaran online pada masa sekarang ini sangatlah mudah dengan memanfaatkan modul Learning Management System yang mudah untuk diinstalasi dan dikelola seperti Moodle.

Kepuasan Mahasiswa berasal dari kata kepuasan atau satisfaction berasal dari bahasa latin 'satis' artinya cukup baik atau memadai dan 'facio' yang artinya membuat. Secara sederhana kepuasan dapat diartikan sebagai upaya pemenuhan sesuatu atau membuat sesuatu memadai. Menurut Kotler (dalam Rangkuti, 2006) secara umum kepuasan pengguna jasa adalah perasaan senang atau kecewa seseorang sebagai hasil dari perbandingan antara persepsi atau jasa layanan yang dirasakan dan diharapkan. Jika kinerja berada dibawah harapan, maka pengguna jasa tidak puas. Sedangkan jika kinerja memenuhi harapan,maka pengguna jasa layanan puas. Tjiptono (2007) mengungkapkan bahwa kepuasan pelanggan adalah respon pelanggan pada evaluasi persepsi terhadap perbedaan antara ekspektasi awal (standar kinerja tertentu) dan kinerja aktual produk sebagaimana dipersepsikan setelah konsumsi produk.

Sementara itu, Engel, at.al (dalam Tjiptono,2007) menyatakan bahwa kepuasan pelanggan merupakan evaluasi 33 purnabeli dimana alternatif yang dipilih sekurangkurangnya sama atau melampaui harapan pelanggan, sedangkan ketidak puasan timbul apabila hasil tidak memenuhi harapan. Secara umum, kepuasan Mahasiswa didefinisikan sebagai respon pengguna jasa terhadap kesesuaian antara tingkat kepentingan sebelumnya dan kinerja aktual yang dirasakan setelah pemakaian. Oleh karena itu, agar pelayanan dapat memuaskan Mahasiswa, maka pegawai yang bertugas melayani harus memenuhi empat kriteria pokok menurut (Moenir,2006) yaitu : 1. Tingkah laku yang sopan; 2. Cara menyampaikan sesuatu yang berkaitan dengan apa yang seharusnya diterima oleh orang yang bersangkutan; 3 . Waktu menyampaika yang tepat; 4. Keramah tamahan. Dari keseluruhan kegiatan yang dilakukan oleh sebuah perguruan tinggi, pada akhirnya akan bermuara pada nilai yang akan diberikan oleh mahasiswa mengenai kepuasan yang dirasakan.

Menurut Kotler (dalam Lupiyoadi, 2001) Kepuasan merupakan tingkat dimana perasaan di mana seseorang menyatakan hasil perbandingan atas kinerja produk/jasa yang diterima dan diharapkan. Sedangkan Kottler (dalam Sihombing, 2003), mendefinisikan kepuasan pelanggan adalah kepuasan atau kekecewaan yang dirasakan oleh pelanggan setelah membandingkan antara harapan dengan kenyataan yang ada. Engel, Blackwell dan Miniard (dalam Widyaratna dan Chandra,2001), mendefinisikan kepuasan sebagai evaluasi pasca konsumsi dimana suatu alternatif yang dipilih setidaknya memenuhi atau melebihi harapan. Singkat kata, alternatif tersebut setidaknya terlaksana sebaik yang anda harapkan. Ada kesamaan diantara beberapa definisi diatas, yaitu menyangkut komponen kepuasan pengguna jasa (harapan dan kinerja atau hasil yang dirasakan). Umumnya harapan pengguna jasa merupakan perkiraan atau keyakinan tentang apa yang diterimanya bila menggunakan jasa). Sedangkan kinerja yang dirasakan adalah persepsi pengguna jasa terhadap apa yang ia terima setelah mendapatkan layanan jasa tersebut.

Kepuasan pengguna Jasa adalah suatu perasaan senang atau kecewa dari seseorang pengguna layanan jasa ketika dia membandingkan persepsinya terhadap 'current performance' suatu produk atau jasa dengan ekspetasinya. Jadi, jika performance sama atau bahkan melebihi, baru ada kepuasan (Darmadi, 2000) Dimensi dari kepuasan 1. Sesuai yang diinginkan 2. Mendapatkan apa yang diinginkan 3. Kepuasan menyeluruh Menurut Irawan (2002) kepuasan akan terjadi jika lembaga mampu menyediakan produk, pelayanan, harga dan aspek lain sesuai dengan harapan atau melebihi harapan pelanggan. Maka kepuasan pelanggan didapatkan dari suatu pelayanan (jasa) atau produk yang sesuai dengan harapan. Dari penjelasan di atas da[at diketahui bahwa kepuasan mahasiswa akan terjadi jika universitas mampu menyediakan produk, pelayanan, harga dan aspek lain sesuai dengan harapan atau melebihi harapan mahasiswa nya. Maka kepuasan mahasiswa didapatkan dari suatu pelayanan (jasa) atau produk yang sesuai dengan harapan mereka. 


\section{METODE PENELITIAN}

Penelitian ini merupakan penelitian survey yang dilaksanakan di beberapa perguruan tinggi Sumatera Utara yang telah dilaksanakan pada bulan April 2020. Pada penelitian ini menggunakan teknik total sampeling dimana mahasiswa pada perguruan tinggi tersebut diberikan angket tertutup melalui google form yang diisi sebagai perwakilan sekolah tersebut. Pada angket terdapat 20 kuesioner seputar penggunaan media e-lerning dengan 5 Variabel yang akan diteliti yaitu: (1) perangkat pembelajaran, (2) efektifitas pembelajaran, (3) media yang digunakan, (4) kemampuan dosen dalam memanfaatkan media dan (5) kemampuan mahasiswa dalam menggunakan media. Populasi dalam penelitian ini adalah mahasiswa progrm studi S-1 (seluruh jurusan) dan aktif pada semester 4, Sampel diambil sejumalh 220 responden yang meliputi seluruh wilayah di Sumatera Utara.

Analisis data dengan analisis deksriptif kualitatif yang disajikan dalam kategori berupa persentase. Rumus yang digunakan untuk mencari besarnya frekuensi relatif (persentase) adalah:

$$
p=f n \times 100 \%
$$

Keterangan:

$\mathrm{f}=$ frekuensi yang sedang dicari persentasenya.

$\mathrm{n}=$ number of cases (jumlah frekuensi dan banyaknya individu).

$\mathrm{p}=$ angka persentase. (Anas Sudijono, 2011)

\begin{tabular}{ccc}
\hline No & Persentase Nilai & Keterangan \\
\hline 1. & $76 \%-100 \%$ & Baik \\
\hline 2. & $56 \%-75 \%$ & Cukup \\
\hline 3. & $40 \%-55 \%$ & Kurang \\
\hline 4. & $<40 \%$ & Buruk \\
\hline
\end{tabular}

\section{HASIL DAN PEMBAHASAN}

Hasil penelitian menjelaskan kelima Variabel yang diteliti yaitu: (1) perangkat pembelajaran, (2) efektifitas pembelajaran, (3) media yang digunakan, (4) kemampuan dosen dalam memanfaatkan media dan (5) kemampuan mahasiswa dalam menggunakan media dalam tabel berikut:

Tabel 1. Tingkat Kepuasan Mahasiswa Terhadap Penggunaan Media E-Learning Di Era Pandemi covid 19

\begin{tabular}{clcc}
\hline No & \multicolumn{1}{c}{ Indikator } & Rata-rata & Persentasi \\
\hline 1 & Perangkat pembelajaran & 922 & 83.80 \\
\hline 2 & Efektifitas pembelajaran & 703 & 63.91 \\
\hline 3 & Media Pembelajaran & 908 & 82.52 \\
\hline 4 & Ketrampilan Dosen & 987 & 89.73 \\
\hline 5 & Ketrampilan Mahasiswa & 853 & 77.55 \\
\hline
\end{tabular}

Dari data tersebut terlihat bahwa indikator perangkat pembelajaran yang dirancang dalam perkuliahan berupa Silabus, RPP dan Kontrak Kuliah sudah sesuai dengan kaidah keilmuan yang telah disesuaikan dengan kondisi saat ini, terlihat hasil survey menunjukkan rata-rata skor 922 dengan persentasi 83.80 yang jika dikonversikan dalam norma mendapatkan predikat "Baik". Selanjutnya pada indikator kedua terlihat bahwa efektifitas pembelajaran belum mendapat respon yang baik, terlihat hasil survey menunjukkan rata-rata skor 703 dengan persentasi 63.91 yang jika dikonversikan dalam norma mendapatkan predikat "Cukup". Selanjutnya pada indikator ketiga terlihat bahwa media pembelajaran yang digunakan telah mendapat respon yang baik, terlihat hasil survey menunjukkan rata-rata skor 908 
dengan persentasi 82.52 yang jika dikonversikan dalam norma mendapatkan predikat "Baik". Selanjutnya pada indikator keempat terlihat bahwa Keterampilan Dosen dalam mengembangkan pembelajaran mendapat respon yang baik, terlihat hasil survey menunjukkan rata-rata skor 987 dengan persentasi 89.73 yang jika dikonversikan dalam norma mendapatkan predikat "Baik". Dan pada indikator kelima terlihat bahwa keterampilan mahasiswa dalam menggunakan media e-learning mendapat respon yang baik, terlihat hasil survey menunjukkan rata-rata skor 853 dengan persentasi 77.55 yang jika dikonversikan dalam norma mendapatkan predikat "Baik". Untuk lebih jelasnya dapat dilihat pada diagram berikut.

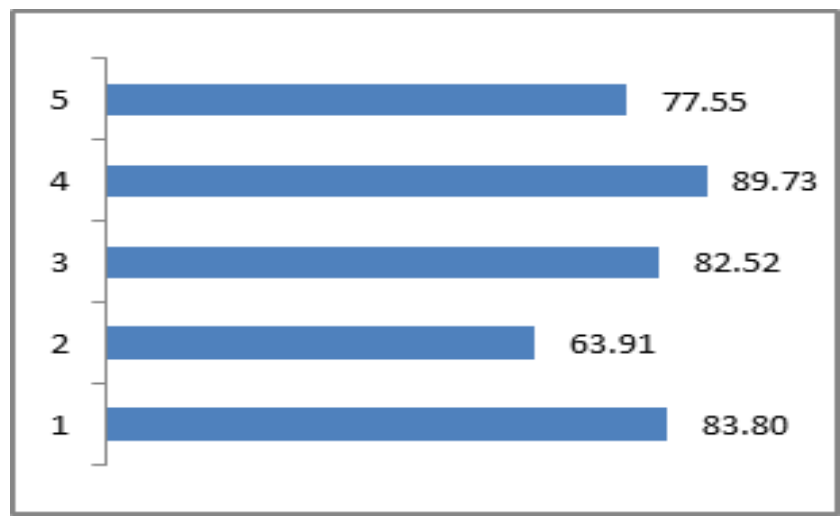

\section{Gambar 1. Tingkat Kepuasan Mahasiswa Terhadap Penggunaan Media E-Learning Di Era Pandemi Covid 19}

\section{SIMPULAN}

Dari data tersebut terlihat terlihat bahwa keterampilan dosen dalam menyajikan perkuliahan baik dalam penyediaan bahan ajar, penggunaan media sudah sangat baik dan didukung lagi oleh kemampuan mahasiswa dalam mengoprasikan media e-learning tersebut. Namun pada sisi efektifitas penggunaan media e-learning dalam pembelajaran Daring (dalam jaringan) dinilai belum efektif menginagt cakupan atau luas negara Indonesia yang penyebaran pembangunannya jaringan internetnya belum merata pada setiap pelosok negeri. Inilah yang menjadi kendala dalam penggunaan media e-learning pada dunia pendidikan.

\section{DAFTAR PUSTAKA}

Munir. (2009). Pembelajaran jarak jauh berbasis teknologi informasi dan komunikasi. Bandung: Alfabeta. Nauman,E. \& Giel, K. (1995). Customer satisfaction and management:Using the voice of The customer. Cincinati: Thomson Executive Pres

Neuman, W L. 2005. Social Research Methods Qualitative and Quantitative Approaches. 3rd ed. By Allyn \& Bacon: A Viacom Company, US

Perhimpunan Dokter Paru Indonesia. 2020. Panduang Praktik Klinis: Pneumia 2019-nCoV. PDPI: Jakarta

Relman, E. 2020. Business Insider Singapore. Cited Jun 21th 2020. Availabel on: https://businessinsider.sg/deadly-china-wuhan-virusspreading-human-to-human-officials-confirm2020-1/?r=US7IR=T

Rusman, dkk. (2011). Pembelajaran berbasis teknologi informasi dan komunikasi, mengembangkan profesionalitas guru. Jakarta: PT. Raja Grafindo.

Seok, Soonhwa. (2008). The aspect of elearning. International Journal on ELearning, Proquest, 7(4), 725 741.

Simanjuntak, 2013, Kualitas Pelaksanaan Tutorial Tatap Muka S-1 Pendas di UPBJJ-Pangkalpinang. Jurnal PTJJ Vol 14.2 september 2013, 120-131.pdf 